\title{
Ijtihad, Pendidikan, dan Politik dalam Pemikiran Muhammad Rasyid Ridha
}

\author{
Jarman Arroisi, Adi Rahmat Kurniawan \\ Universitas Darussalam Gontor, Ponorogo \\ email: jarman@unida.gontor.ac.id adiairrami@gmail.com
}

\begin{abstract}
Abstrack
The problem of religiosity is one of the themes that characterize the modern era today. This problem was marked by widespread issues of secularization, liberalization and pluralism which triggered reactions from Muslim scientists, such as Muhammad Rasyid Ridha. This text aims to examine Rosyid Ridha's thoughts on the theme of ijtihad, education and politics. By using the analytical descriptive method, this study concludes several important points. First, Rasyid Ridha contributed effectively from all aspects of benefit in the fields of ijtihad, education and politics. He includes religious elements that refer to the Al-Qur'an and Hadith, such as in his teacher Jamaluddin AlAfghani. Second, he offers a well-known solution, namely by re-buzzing ijtihad. And third, taking modern thinking and then integrating it with Islam without eliminating syari'ah values. In Rida's concept of thought, he always combines Western and Islamic sciences but still prioritizes religion based on the Al-Qur'an and Hadith. Because of this, his thinking is considered to be a solution in facing the modern era today.
\end{abstract}

Keywords: Relegiusity, Muhammad Rasyid Ridha, Ijtihad, Syari'ah

\begin{abstract}
Abstrak
Problem relegiusitas merupakan salah satu tema yang mewarnai era modern saat ini. Problem tersebut ditandai dengan merebaknya isu sekularisasi, liberalisasi, dan pluralisme yang memicu reaksi para ilmuan Muslim, termasuk Muhammad Rosyid Ridha. Naskah ini bertujuan mengkaji pemikiran Rosyid Ridha tentang tema ijtihad, pendidikan, dan politiknya. Dengan menggunakan metode deskriptif analitik kajian ini menyimpulkan beberapa poin penting. Pertama, Rasyid Ridha memberikan kontribusi yang efektif dari segala aspek kemashlahatan dalam bidang ijtihad, pendidikan dan politik. Ia memasukkan unsur-unsur religi yang mengacu kepada Al-Qur'an dan Hadits, seperti pada gurunya Jamaluddin Al-Afghani. Kedua, ia menawarkan solusi yang terkenal yaitu dengan kembali mendengungkan ijtihad. Dan ketiga, mengambil pemikiran modern kemudian memadukannya dengan Islam tanpa menghilangkan nilai-nilai syari'ah. Dalam konsep pemikiran Ridha ia selalu memadukan antara ilmu Barat dan Islam akan tetapi tetap mengedepankan agama dengan berasaskan Al-Qur'an dan Hadits. Karena inilah, pemikirannya dianggap menjadi solusi dalam menghadapi era modern saat ini .
\end{abstract}

Kata Kunci: Relegiusitas, Muhammad Rasyid Ridha, Ijtihad, Syaria'h

\section{Pendahuluan}

Perkembangan pemikiran Islam membawa dampak yang signifikan dalam sejarah peradaban modern saat ini, baik dalam segi keilmuan dan tekhnologi. Peradaban yang dibawa Islam mencakup aspek yang sangat luas bukan hanya mencakup budaya, kota, ekonomi dan keadaan sosial. Menurut Imam Badri peradaban Islam yaitu al-hadharah alIslamiyah adapun kebudayaan dimaknai sebagai at-Tsaqafah ${ }^{1}$. Melalui pemikiran

1 Mugiono, "Perkembangan Pemikiran dan Peradaban Islam dalam Perspektif Sejarah", Jurnal Ilmu 
yang dibawa Muhammad Rasyid Ridha menandakan bahwa agama Islam dapat mengikuti perkembangan zaman tanpa adanya pengaruh dari bangsa Barat. Sebab, sejatinya Ridha berhasil mengimplementasikan hasil pemikirannya kedalam beberapa aspek diantaranya ijtihad, pendidikan, dan bahkan politik.

Kajian pemikiran Rasyid Ridha merubah umat Islam yang enggan menerima modernitas ilmu pengetahuan dengan alasan takut masuknya paham Barat kedalam agama, dengan penolakan ini Islam berada dalam kejumudan dan mengikuti tradisi-tradisi yang kontra akan perkembangan zaman. Padahal perkembangan pemikiran dalam Islam dimaknai dengan al-Hadharah al-Islamiyah yang berarti kemajuan kebudayaan secara Islam. Secara garis besar kemajuan ialah kegaitan yang dilakukan manusia guna untuk mencari sebab dan akibat asal mula dari sesuatu sehingga dapat diketahui esensinya, hal inilah yang menjadi kajian objek pemikiran Islam².

Dalam pembahasan ini, jelaslah bahwa sasaran pemikiran yang dibawa Rasyid Ridha menjurus pada 3 aspek; ijtihad, pendidikan dan politik. Pertama, perlu adanya rekonstruksi hukum dengan

Agama: Mengkaji Doktrin, Pemikiran, dan Fenomena Agama, Vol. 14 No 1 (2013), hlm. 4.

2 Nyimas Umi Kalsum, Perkembangan Pemikiran dan Peradaban Islam pada Abad Modern, (UIN Raden Patah). p. 33. cara mengembalikannya kedalam Syaria't sebagaimana yang diajarkan oleh Rasullullah, Kedua, pendidikan berbasis Islam merupakan solusi dari konteks pluralistas yang ada di Indonesia, hal ini selaras dengan pendapat Nuryanto bahwa dengan pendidikan Islam umat Muslim dapat membuka dan proporsional melihat perbedaan keyakinan ${ }^{3}$. Ketiga, ditengah maraknya isu Pluralisme politik Islam dapat dijadikan sebagai solusi penegakan hukum, karena sejatinya Islam menjunjung tinggi aspek keadilan dan mengedepankan sesetaraan kedudukan dimuka undang-undang4.

\section{Biografi Muhammad Rasyid Ridha}

$$
\text { Memiliki nama lengkap }
$$

Muhammad Rasyid Ridha Ibn Ali Ridha Ibn Muhammad Syamsuddin Ibn Muhammad Bahauddin Ibn Manla Ali Khalifah dilahirkan di Qalamun', Kota Libanon pada tahun 1282 H/1865 M-1354 H/1935 H. Adapaun saat itu daerah Libanon merupakan wilayah dari Kerajaan Turki Utsmani. Orang tua Rasyid

${ }^{3}$ Ulfa Masamah, Mualimul Huda, "Pendidikan Islam, Pendidikan Politik, dan Dialog Antar Umat Beragama di Indonesia", Fikhrah; Jurnal Ilmu Aqidah dan Studi Keagamaan STAIN Kudus", Desember 2016, hlm. 4.

4 Ulfa Masamah, Mualimul Huda, Pendidikan Islam, Pendidikan Politik, dan Dialog Antar Umat Beragama di Indonesia, p. 10.

5 Qalamun atau Al-Qalamun (bahasa Arab : (القلمون adalah kota tepi laut Mediterania dari Governoat Utara Lebanon di Distrik Tripoli. Kota ini $5 \mathrm{~km}$ selatan Tripoli dan juga merupakan kota pertama Tripoli, https://en.wikipedia.org/wiki/Al-Qalamoun 
Ridha berasal dari keturunan al-Husayn putra Ali bin Abi Thalib dengan Fatimah Putri Rasulullah. Oleh sebab itu, Rasyid Ridha mendapatkan gelar Sayyid didepan namanya atau karena ayah beliau yaitu alSayyid Ali Ridha yang merupakan seorang Sunni bermadzhab Syafi'i ${ }^{6}$. Ketika Muhammad Rasyid Ridha kecil, ia menghabiskan waktunya dengan belajar dan membaca buku karena ia sangat cinta dengan ilmu pengetahuan.

Riwayat pendidikan beliau dimulai ketika ia lancar membaca kemudian masuk di Madrasah alRasyidiyah, yaitu sekolah milik pemerintah di kota Tripoli. Didalam sekolah tersebut, M. Rasyid Ridha belajar beberapa diantaranya ; berhitung, bahasa (qowai'd), ilmu bumi, dan agama. Kemudia ia melanjutkan pendidikannya ke Madrasah al-Wathaniyah al-Islamiyyah yang didirikan oleh Syekh Husein al-Jisr ketika umur 18 tahun.Di Madrasah ini lebih maju dengan pendidikan Rasyid Ridha sebelumnya, sebab ia mulai belajar mantik, matematika, filsafat dan ilmu agama lainnya. Gurunya Syekh Husein al-Jisr sangat berjasa terhadap pemikiran yang telah digagas Rasyid Ridha kelak, karena ia yang mengantarkannya bertemu

${ }^{6}$ Andi Mappiaswan (Skripsi Mahasiswa Sarjana Humaniora Jurusan Sejarah dan Kebudayaan Islam, Fakultas Adab dan Humaniora UIN Alauddin Makassar), Pemikiran Sayyid Muhammad Rasyid Ridha dalam Pengembangan Islam, p. 14. dengan bertemu dengan 2 tokoh pembaharuan dunia Islam yang sangat dikagumi yaitu Muhammad Abduh dan Jamaluddin al-Afghani di Mesir. Melalui surat kabar berbahahasa Arab bernama "al-'Urwah al-Wusqa", ia juga banyak belajar dan mengenal mereka berdua. Hingga pada akhirnya, Lewat bimbingan Muhammad Abduh, Rasyid Ridha menafsirkan Al-Qur'an sesuai tuntunan zaman kemudian diterbitkan kedalam majalah "al-Manar" hingga dibukukan menjadi "Tafsir al-Manar" sampai saat ini7. Setelah kepergian guru Rasyid Ridha yang bernama Jamaluddin al-Afghani, ia kemudian pergi ke Kairo pada tahun 1897 dengan tujuan mengikuti tokoh ilmuan terkenal yaitu Muhammad Abduh.

Sayid Muhammad Rasyid Ridha meninggal pada Kamis, 23 Jumadil U'la $1354 \mathrm{H}$ atau bertepatan dengan 22 Agustus 1935. Semasa hidupnya, beliau telah mengarang beberapa kitab diantaranya ${ }^{8}$; 1).Al-Hikmah asy-Syar'iyah fi Muhakamat al-Dariyah wa al-Rifai'yah merupakan karya beliau yang pertama ketika belajar. 2).Al-Azhar dan al-Manar yang berisi tentang Al-Azhar di Kairo.

7 Nasruddin Yusuf, "Perbandingan Pemikiran Muhammad Abduh dan Rasyid Ridha tentang Pendidikan", Jurnal Sosial Budaya, Vol. 8 No. 01 Januari Juni 2011, hlm. 75.

${ }^{8}$ Irvansyah, Skripsi (Pemikiran Muhammad Rasyid Ridho tentang Pembaharuan Pendidikan Islam), Fakultas Tarbiyah dan Keguruan UIN Raden Intan Lampung, Tahun 2018, p. 89. 
3).Tarikh al-Ustadz al-Imam berisi guru beliau yaitu Muhammad Abduh. 4).Nida' li al-Jins al-Lathif berisi tentang hak dan kewajiban wanita. 5).Zikra al-Maulid anNabawi, 6).Risalatul Hujjah al-Islam alGhazali, 7).Al-Sunnah wa al-Syia'h, 8).AlWahdah al-Islamiyyah, 9).Haqiqah ar-Riba, 10).Majalah al-Manar, 11).Tafsir al-Manar, 12).Tafsir surah-surah al-Ikhlas, al-Kafirun dan al-Mu'awwidzatin.

\section{Pembaharuan Menurut Rasyid Ridha}

Seiring berkembangnya zaman, manusia mau tidak mau akan dihadapi dengan beberapa tantangan berupa ilmu pengetahuan, gerakan ideologi, serta pemahaman baru, baik yang sifatnya didalam maupun diluar ajaran agama Islam. Tujuannya tak lain ialah supaya umat Islam mengikuti tren moderenitas yang berkembang dengan dalih sebagai tuntunan perkembangan zaman. Akan tetapi, hal semacam ini membuat kerancuan bagi umat Islam yang mana AlQur'an dan Hadist dijadikan sebagai klaim fundamental dan radikal beralih menjadi fleksibelitas. Sebab, nilai kontribusi kemajuan banyak disokong oleh Barat dengan ajarannya yaitu Katholik dan Protestan. Sehingga pada akhirnya, paham semacam ini memunculkan ide baru yaitu sekularisi, liberalisasi, dan nihilisasi yang mana kesemuanya itu menjauhkan kita dari agama.

Pembaharuan dalam Islam dimaknai dengan kata modern (alhadharah al-islami) dengan mengintegrasikan nilai-nilai keagamaan didalamnya. Al-Qur'an dan Hadist sebagai rujukan yang otentik dan asas ilmu pengetahuan, serta mengikuti petunjuk ulama-ulama salaf ash-shalih terdahulu. Bahkan Rasyid Ridha menambahkan perlunya tidak membabi buta dalam memahami madzahib dengan zaman yang tidak relevan saai ini ${ }^{9}$. Beliau juga menyarankan agar diadakan reformasi sistem Islam seperti pemerintahan menjadi khilafah. Ia juga sepakat bahwa sistem semacam ini akan melindungi agama dan bisa mengatur dunia. Hal inilah yang mendorong pemikir-pemikir Islam seperti Muhammad Rasyid Ridha untuk mencari alternatif dengan tidak mengadopsi ide Barat. Karena suatu peradaban yang maju tidak dilihat dari aspek tekhnologi semata, akan tetapi lebih berpengaruh bila bermunculan gerakan-gerakan intelektual ${ }^{10}$. Menurut Rasyid Ridha

\footnotetext{
9 Sumper Mulia Harahap (Lecture of Syaria'h dan Law Science Faculty at IAIN Padangsidimpuan), Muhammad Rasyid Ridha Antara Modernisme dan Tradisionalisme, p. 254.

10 N. Arkiyah Artikel dengan Judul Tokoh Pembaharuan Muslim Arab Modern dan Kontribusinya terhadap Kepustakaan Islam (Muhammad Abduh dan Sayyid Muhammad Rasyid Ridha, Tahun 2017, p. 2.
} 
pembaharuan pemikiran Islam hukumnya mutlak harus dilakukan sebab, seiring berkembangnya zaman umat Islam mulai melupakan ajaran murninya ${ }^{11}$. Adapun cara yang paling efektif melakkan pembaharuan pemikiran Islam yaitu melalui politik, kemudian pendidikan dan pengajaran.

Pembaharuan yang dibawa Rasyid Ridha tidak jauh berbeda dari gurunya yaitu Muhammad Abduh. Ia berpendapat perlunya ijtihad dalam pemecahan masalah agama, serta pentingnya mempelajari tekhnologi yang berkembang di Barat kemudian diaktualisasikan menurut pandangan Islam ${ }^{12}$. Karena sejatinya, kemajuan dizaman klasik merupakan hak otentik umat Islam sebab ia mengambil milik agama lain. Oleh karena itu, mempelajari Barat berarti merebut kembali ilmu pengetahuan milik Islam. Sedangkan menjauhkan diri dari tekhnologi akan membuat umat Islam semakin mundur dari ketertinggalan dan imbasnya berujuang kepada agama.

Dalam memaknai pembaharuan, manusia dapat mengambil beberapa manfaat/hibroh dari suatu kejadian sehingga dapat meneladani kisah-kisah terdahulu serta mengambil hikmahnya.

\footnotetext{
11 Andi Mappiaswan, Pemikiran Sayyid Muhammad Rasyid Ridha dalam, p. 41.

12 Muhammad Yasin, Kegelisahan Muhammad Abduh dan Rasyid Ridha atas Keberagaman Umat Islam dan Pemikiran Tauhid Muhammad Abduh dan Rasyid Ridha, p. 8.
}

Diantara manfaat pembaharuan Islam yaitu $^{13} ;$ 1).Mengambil hikmah serta pelajaran dari Al-Qur'an yang menjelaskan tentang kisah-kisah terdahulu. 2).Memperoleh petunjuk dan keselamatan, 3).Memunculkan ide-ide baru, 4).Motivasi untuk masa depan. Dengan belajar banyaknya manfaat pembaharuan diharapkan manusia dapat memperkuat aqidah Islam dan semakin cintanya terhadap ilmu pengetahuan, maka semakin kuatlah pendiriannya.

\section{Pemikiran Rasyid Ridha tentang Ijtihad}

Secara istilah kata 'ijtihad' berasal dari Masdar kata "al-juhd" atau "juhd" yang berarti "al-masyaqot" (kesusahan atau kesulitan). Akan tetapi dilihat dari fi'il madhi yaitu ijtahada berarti usaha untuk lebih bersungguh-sungguh ${ }^{14}$. Dalam etimologinya, ijtihad bermakna pengerahan segala kemampuan untuk menyelesaikan segala permasalahan yang sulit. Sedangkan dalam pengertian etimologi berarti penyelesaian segala masalah dengan mengacu pada kitabullah (Al-Qur'an) dan hadist nabi guna untuk mendapatkan hasil final atau mashlahat.

\section{Islam,}

13 Kamilla Riska Tiastuti, Makalah Pembaharuan https://www.academia.edu/42113023/MAKALAH_PEM BAHARUAN_ISLAM, p. 14.

14 Abd Wafi Has, Ijtihad Sebagai Alat Pemecah Masalah Umat Islam, Sekolah Tinggi Keislaman Al-Hidayah (STIKA) Arjasa, p. 91. 
Sementara itu, syariat menurut bahasa berarti "jalan menuju air", atau kearah pokok sumber kehidupan yaitu kembali pada Al-Qur'an dan Hadits. Pemikiran Rasyid Ridha mengenai ijtihad sebagai hukum Islam didasarkan pada Hadits nabi yang Artinya : "bahwa Nabi Muhammad saw ketika Muaz ke yaman, nabi berkata: bagaimana engkau mengambil keputusan hukum terhadap permasalahan yang diajukan kepadamu? Muaz menjawab: saya akan mengambil keputusan hukum berdasarkan kitab allah. Kalau engkau tidak menemukan dalam Al-Qurean? Tanya nabi, muaz menjawab: saya akan mengambil keputusan dengan sunnah rosul ? jawab muaz: saya akan berijtihad dengan akal saya dan tidak akan bersantai-santai, lalu rosullah menepuk dadaku seraya mengatakan : segala puji bagi allah yang telah membuat taufiq kepada utusan rosulnya terhadap sesuatu yang diridhoi oleh rosullah saw.(H.R. Ahmad,Abu Dawud, Tirmidzi)

Adapun ruang lingkup ijtihad para ulama menetapkan bahwa ada yang boleh mengkajinya dan adapula yang tidak. AlGhazali berpendapat bahwa ijtihad hanya dapat dilakukan terhadap hukum syar'i yaitu diluar pengetahuan akal dan ilmu kalam. Penegasan tersebut memberikan arti bahwa ijtihad bersifat objektif (jelas) dan dapat didiskusikan, sedangkan masalah yang qat'i hukumnya adalah tsawabit ${ }^{15}$. Sementara itu, Ali Hasballah berpendapat bahwa ruang lingkup ijtihad adalah masalah-masalah yang terdapat diluar Al-Qur'an dan Hadits, maka solusi pemecahan masalahnya tidak lain yaitu menggunakan ijtihad disebabkan karena ruang lingkup kajiannya yang luas ${ }^{16}$.

Alasan Rasyid Ridha menetapkan ijtihad sebagai penetapan hukum tidak lain bahwa didalam Al-Qur'an terdapat 510 ayat menjelaskan tentang politik, sedangkan selebihnya yaitu ibadah dan muamalah. Sedangkan jika merujuk pada hadits ahkam ada sekitar 500 dari 4000 berbicara tentang politik. Oleh karena itu, penggunaan ijtihad sangat penting sebab nabi juga telah mensetujuinya dengan syarat ada sandaran yang otentik baik dari Al-Qur'an maupun Hadits nabi ${ }^{17}$.

Dalam ijtihad, Rasyid Ridha memberikan peran penting umara' sebagai kepala pemerintahan dalam menjalankan kewajibannya. Oleh sebab itu, ia membagi menjadi 2 dalam menetapkan suatu hukum ; pertama, ijtihad melalui ijma' yang dilakukan oleh mujtahid. Kedua, ijtihad yang dilakukan

\footnotetext{
15 Abd. Salam Arief, "Ijtihad dan Dinamika Hukum Islam", In Right Jurnal Agama dan Hak Azazi Manusia, hlm. 9.

16 Abd. Salam Arief, "Ijtihad dan Dinamika Hukum Islam", hlm. 10.

17 Ahmad Sanusi , Pemikiran Rasyid Ridha tentang Pembaharuan Islam, p. 39.
} 
oleh penguasa dalam masalah pemerintahan, birokrasi, dan militer. Hal ini sesuai yang difirmankan Allah SWT dalam surah al-Nisa ayat 59 :

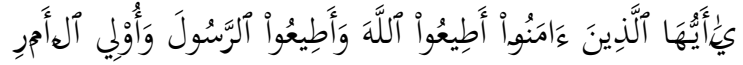

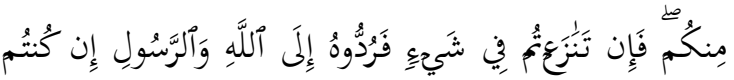

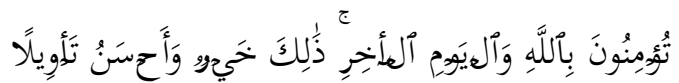
"Hai orang-orang yang beriman, taatilah Allah dan taatilah Rasul (Nya), dan ulil amri di antara kamu. Kemudian jika kamu berlainan pendapat tentang sesuatu, maka kembalikanlah ia kepada Allah (Al Quran) dan Rasul (sunnahnya), jika kamu benar-benar beriman kepada Allah dan hari kemudian. Yang demikian itu lebih utama (bagimu) dan lebih baik akibatnya".

Dalam pelaksanaan ijtihad, mujdahid harus mempunyai kriteriakriteria yang pantas dan memadai sehingga ia berhak melakukan ijtihad. Dr. Yusuf Qardawi sebagai ulama klasik memberikan beberapa syarat yang harus dipenuhi seorang mujtahid diantaranya ${ }^{18}$; a). Mujtahid fi Syar'i (Orang yang mengetahui seluruh permasalahan), b). Mujtahid fi al-Masail (Mengarah kepada pokok permasalan), c). Mujtahid fi alMadhab (Mujtahid yang mengikuti salah satu imam madzhab dan tidak membentuk madzhab baru). d). Mujtahid Muqayyad (Mengikuti pendapat ulama), e). Mujtahid Muntasib (Mengkaitkan imam

18 Misno, "Redefinisi Ijtihad dan Taklid", AlMashalah Jurnal Hukum dan Pranata Sosial Islam, hlm. 395. dan murid), f). Mujtahid Tarjih (Bersikap profesional dalam memilih pendapat).

Oleh karena itu, Rasyid Ridha memilih konsep ijtihad sebagai sarana untuk mengentaskan umat Islam dari ketertinggalan sebagaimana yang telah diajarkan Nabi Muhammad SAW. Yaitu kembali kepada ajaran Al-Qur'an dan lebih mentadaburinya kembali. Sebab, syariat Islam memberikan peluang untuk berbuat ijtihad sehingga bisa mengambil istinbat dari suatu permasalahan yang pada akhirnya akan diperoleh sisi mashlahah ${ }^{19}$. Dengan semangat ijtihad inilah para ulama mengerahkan kemampuannya untuk memecahkan masalah-masalah kontemporer sehingga dapat ditemukan solusi permasalahannya. Kaitannya dengan ini, perlu diketahui bahwa sesungguhnya prinsip ilmu pengetahuan didalam Al-Qur'an dan Hadits bersifat implisit (tidak dinyatakan secara jelas meskipun keduanya merupakan sumber yang otentik, maka dari itulah perlu digaungkan semangat ijtihadiyah dalam Islam sebagai dinamika ajarannya.

Gagasan Pembaharuan dalam Bidang Pendidikan

${ }_{19}$ Agus Ahmad, Sejarah Pembaharuan Pemikiran dan Pembaharuan Rasyid Ridha, p.12 
Secara etimologi pendidikan berasal dari 2 kata yaitu "didik" yang mendapatkan awalan 'pen' dan akhiran 'an'. Sedangkan dalam bahasa Arab sering disebut dengan tarbiyah, ta'dib dan ta'lim. Dalam Ensiklopedia Pendidikan istilah ini dijelaskan sebagai mengintegrasikan keilmuan dari generasi tua kegenerasi muda sebagai upaya memenuhi kebutuhan jasmani dan rohani ${ }^{20}$. Menurut M. Yusuf al-Qardawi pendidikan Islam yaitu melibatkan 4 unsur yaitu akal, hati, jasmani dan rohani. Sementara Atiyah alIbrasyi berpendapat bahwa pendidikan Islam ialah hal-hal yang berkaitan dengannya menyangkut moral, jiwa dan etika sehingga memperoleh bekal keselamatan didunia dan akhirat ${ }^{21}$.

Menurut Muhammad Rasyid Ridha dalam memajukan pendidikan berbasis agama Islam diantaranya dengan mendirikan sekolah bernama Madrasah alDa'wah wa al-Irsyad pada tahun 1912 di Kairo, dengan tujuan mencetak kaderkader mubaligh sebagai imbangan dari misisonaris Kristen. Ia juga mengirimkan para alumninya keberbagai penjuru dunia sebagai penggerak pembaharuan Islam yang kembali pada Al-Qur'an dan Hadist. Sebab itulah, Muhammad Rasyid Ridha

\footnotetext{
20 Zaunudin, "Pembaharuan Sistem Pendidikan Islam", Jurnal Risaalah, Vol. 1 No 1 Desember 2015, hlm. 4.

21 Zaunudin, Pembaharuan Sistem Pendidikan Islam, hlm. 5.
}

beraliran Wahabi dan condong pada ajaran Ibnu Taimiyah22. Hal tersebut dilakukan karena ia berpendapat bahwa membangun lembaga pendidikan lebih masjid, karena masjid tidaklah tidaklah besar apabila didalamnya diisi oleh orangorang bodoh. Pekerjaan duniawi dan ukrawi akan menjadi baik jika manusia menjadi pandai yaitu dengan cara memperluas pembangunan lembaga pendidikan secara umum.

Dalam melaksanakan pembaharuan dalam bidang pendidikan, Muhammad Rasyid Ridha juga menekankan terhadap kurikulum Qur'ani dengan alasan sebagai kitab suci dan pedoman bagi manusia yang bersifat universalitas $^{23}$. Disamping itu ia juga sebagai sumber ilmu pengetahuan yang derajatnya paling tinggi dan dapat dimengerti oleh orang yang berakal dan berjiwa suci. Oleh karnanya, dalam praktek pendidikan Rasyid Ridha terdapat beberapa keistimewaan yang yaitu ${ }^{24}$; 1).Kurikulum bersifar menyeluruh (ilmu agama dan umum), 2).Mempelajari karyakarya generasi sebelumnya, 3).Sesuai

${ }^{22}$ Asep Hilmi, "Pemikiran Modern Hukum Islam Rasyid Ridha", Staf Dinas Sosial Kabupaten Serang, TAZKIYA Jurnal Keislaman, Kemasyarakatan dan Kebudayaan, hlm. 199.

${ }^{23}$ Moh. Amin Dahlan Thalib, Konsep Pendidikan Al-Qabisy dan M. Rasyid Ridha (Koedukasi dan Kurikulum), p. 12

24 Irvansyah, Skripsi (Pemikiran Muhammad Rasyid Ridho tentang Pembaharuan Pendidikan Islam), p. 102 
dengan kebutuhan masyarakat, 4).Saling melengkapi antara teori dan praktek.

Ide Rasyid Ridha mengembangkan dalam sektor pendidikan ialah karena kurangnya umat Islam dalam penguasaan ilmu pengetahuan dan tekhnologi, akan tetapi hal ini berbeda dengan Barat telah maju. Kemudian timbullah inisiatif bahwa Islam harus menerima tekhnologi karena hal tersebut tidak dilarang dalam agama. Pada hakikatnya, bangsa Barat lah yang mengambil moderenisasi dari keilmuan Islam melalui Spanyol25. Dengan demikian mempelajari keilmuan Barat sebenarnya mengambil kemajuan peradaban Islam sendiri yang telah direbut. Hal ini selaras dengan yang dikatakan Abudin Nata dalam bukunya "Selekta Kapita Pendidikan Islam", ia menyebutkan bahwa dinamika pendidikan Islam dipengaruhi oleh 5 faktor yaitu ; perkembangan ilmu pengerahuan dan tekhnologi, masyarakat, politik, ekonomi dan agama ${ }^{26}$.

Pentingnya memadukan Ilmu pengetahuan dan tekhnologi akan menghasilkan tujuan yang jelas jika dilandasi dengan keimanan, adapun sebaliknya jika tanpa iman maka yang terjadi ialah kebuntuan pemikiran ibarat

25 Anas Amin Aklamsyah, "Pola Pemahaman Agama dan Pengembangan Kependidikan - Kontribusi Rasyid Ridha", Journal Online of Education, STIT Raden Wijaya, Vol. 06 No. 02 Novrmber 2016, hlm. 137.

26 Ahmad Lahmi, "Sejarah Pendidikan Islam dari Masa ke Masa", Jurnal AKADEMIA, hlm. 2. seperti orang buta ${ }^{27}$. Sebab itulah, pentingnya peranan Al-Qur'an sebagai wahyu yang otentik sehingga bisa membawa manusia mengembangkan ilmu pengetahuan dan tekhnologinya. Adapun ia juga dapat mengangkat dapat mengangkat derajat orang-orang yang berilmu sebagaimana yang dijelaskan oleh Allah SWT dalam Surah al-Mujadalah : 11.

\section{Pembaharuan dalam Bidang Politik dan} Hukum

Menurut bahasa Arab politik berarti "as-Siyasah" yang merupakan akar dari kata 'sasa-yasusu' artinya mengatur, mengurusi, memerintah. Secara singkat politik dalam Islam merupakan sistem untuk mengatur sebuah pemerintahan dengan asas religi demi mendapatkan sisi kemashlahatan. Adapun menurut Ibnu Qayyim politik Islam merupakan segala perbuatan yang akan membawa manusia kepada kemashlatan dan menghindari dari kemudharatan ${ }^{28}$. Dalam Kamus Besar Bahasa Indonesia (KBBI) politik memiliki 3 makna yaitu adanya ilmu pengetahuan, Tindakan meliputi urusan pemerintahan, dan kebijaksanaan ${ }^{29}$. Ramlan Surbakti

\footnotetext{
${ }_{27}$ H. Muhammad Baharun, Islam Idealitas Islam Realitas, (Jakarta ; Gema Insani, 2012). p. 72.

28 Abdullah Zawawi, "Politik dalam Pandangan Islam", Jurnal Ummul Quraa, Vol. V, No. 1 Maret 2015, hlm. 86

${ }^{29}$ Rasdah Diana, Siswanto Masruri, Suwardono, "Etika Politik dalam Perspektif Islam", Jurnal TSAQAFAH Volume 14 No. 2 November 2018, hlm. 267
} 
mengartikan bahwa politik merupakan adanya interaksi antara masyarakat dan pemerintah untuk membuat keputusan disuatu daerah. Secara garis besar dapat dimaknai bahwa politik Islam merupakan sebuah sistem yang ditawarkan umat Islam untuk mengurusi suatu negara dengan aturan-aturan terstruktur demi dengan dilandasi agama sebagai asas utama demi terciptanya manfaat dan jauh dari mudharat.

Sejatinya, Islam dan politik merupakan dua unsur yang tidak dapat dipisahkan, agama mencakup kehidupan dunia dan akhirat serta hakikatnya sebagai pedoman hidup bagi manusia untuk mencapai hakikat kebahagiaan. Sedangkan politik merupakan sebuah sistem untuk mengatur pemerintahan yang mana didalamnya terdapat aturanaturan untuk mencapai kesejahteraan. Maka dari itu, hakikat agama dan politik sesungguhnya tidak dapat dipisahkan bahkan bangsa Barat sampai memunculkan istilah sekularisi dengan tujuan untuk memisahkan keduanya, tentu itu merupakan sesuatu yang ambigu dan tidak dapat diterima ${ }^{30}$.

Setelah wafat guru Muhammad Rasyid Ridha, ia mulai aktif didalam

30 Abd. Wahid (Dosen Jurusan Perbandingan Agama Fakultas Ushuluddin IAIN Antasari Banjarmasin), Pemikiran Politik dalam Islam, Ilmu Ushuludiin Januari 2010 Vol. 9 No. 1, p. 76 dunia keperpolitikan Islam terhadap persoalan umat saat itu. Salah satunya yaitu menolak gagasan nasionalisme, karena ia menganggap hal tersebut tidak sesuai dengan ajaran Islam yang mana tidak membeda-bedakan manusia baik dari ras, suku, bangsa dan budaya. Bahkan ia menambahkan ide tersebut dapat memecah-belah umat sehingga menyebabkan kemunduran suatu bangsa $^{31}$. Maka dari itu, solusi sistem pemerintahan yang disusun Rasyid Ridha berbentuk khilafah. Adapun kepala pemerintahannya yaitu khalifah, sedangkan ulama sebagai pembantu pemerintahan Ia juga sepakat dengan pendapat At-Taftazani dan al-Mawardi yang mengatakan bahwa imamah merupakan kepemimpinan yang diwariskan Nabi dalam mengurusi masalah dunia dan akhirat ${ }^{32}$.

Didalam buku karangan Rasyid Ridha yang berjudul al-Khilafah beliau menjelaskan untuk menegakkan urusan agama dan sebuah kepala pemerintahan harus ada khilafah, imamat dan imamat al$u z m a^{33}$. Untuk mempertegas hal itu ditambahkanlah beberapa hal seperti ; pengertian khilafah, pengangkatan

\footnotetext{
31 Yasir Fajri, Pemikiran Politik Islam Muhammad Rasyid Ridha, p. 4

32 Yasir Fajri, Pemikiran Politik Islam Muhammad Rasyid Ridha, p. 5

${ }^{33}$ M. Khoirul Hadi, Pemikiran Politik Rasyid Ridha dalam Figh Munakahat, UIN Sunan Kalijaga, p. 226
} 
khilafah, pihak yang menetapkan khilafah, syarat-syarat khilafah dan sebagainya. Sebagai arahan Rasyid Ridha memberitahukan bahwa betapa pentingnya persatuan, sebab sistem pemerintahan tidak akan berjalan tanpa dibarengi dengan kekompakan Oleh karena itu, perlunya tunduk pada satu keyakinan, sistem pendidikan dan hukum ${ }^{34}$. Ini tentu jauh berbeda dengan konsep yang digaungkang bangsa Barat demi menjatuhkan moralitas agama Islam seakan mereka tak terima dengan kemajuannya.

Menurut Rasyid Ridha khilafah ialah suatu kekuatan besar yang terbentuk dari kesatuan umat sehingga dapat mencapai kemajuan. Contoh yang paling nyata yaitu ketika Turki Utsmani berkuasa rakyatnya makmur dalam naungan Islam. Akan tetapi, setelah sistem khilafah dihapuskan oleh Mustafa Kemal yang ada hanyalah masuknya paham Sekuler Liberal Barat kemudian mengcampur adukannya. Konsep kekhilafahan yang diusung Rasyid Ridho merupakan hasil perenungan pemimping terdahulu ketika zaman khulafauurasyiddin. Walaupun pada akhirnya Rasyid Ridha mengakui bangsa Barat maju dalam perkembangan

${ }^{34}$ M. Khoirul Hadi, Pemikiran Politik Rasyid Ridha dalam Figh Munakahat, UIN Sunan Kalijaga, p. 228 tekhnologi dan ilmu pengetahuan akan tetapi ia kurang setuju akan hal itu.

Menurut Komaruddin Hidayat didalam bukunya ia khilafah menjadi 2 bagian yaitu ; khilafah individual dan sosial/publik ${ }^{35}$. Khilafah individual yaitu sifat yang melekat pada diri manusia keturunan Adam yang lahir tanpa mengenal rasisme. Manusia hanya dibekali sifat-sifat sebatas nisbi/relative diantaranya kehendak (iradah), pengetahuan (ilmu), pendegaran (sama'), bashar (penglihatan) dan sebagainya. Sedangkan Allah SWT memiliki kemampuan yang absolut/mutlak dan diluar nalar manusia. Diantara kisah mengenai Adam layak sebagai khilafah dibandingkan dengan makhluk lainnya seperti jin dan malaikat, telah Allah jelaskan didalam Al-Qur'an yang artinya : “ Dan Allah mengajarkan nama-nama (konsep-konsep) yang ada dibumi, kemudian menyodorkannya kepada malaikat dan berkata, 'Terangkan kepada Kami nama-nama (konsep-konsep) bendabenda dibumi itu, jika kalian (malaikat) memang merasa layak menjadi khalifahNya" 36 .

Sedangkan dari segi kedua yaitu khalifah sosial-politik hanya dibebankan

\footnotetext{
35 Komarudiin Hidayat, Kontroversi Khilafah Islam, Negara dan Pancasila, Mizan, p. 100

36 Al-Qur'an al-Karim, Surah $1: 31$
} 
pada individual tertentu sebagai pemegang kekuasaan pemerintah. Adapun tugas yang ia emban mengatasnamakan kepentingan bangsa dan bukan kepentingan agama tertentu. Doktrin semacam ini sering terdengar dan digaungkan yang terkadang diskriminatif. Akan tetapi, hakekat khalifah menurut Al-Qur'an ialah Allah sebagai khalifah, Presiden sebagai khalifah, Gubernur sebagai khalifah tingkat provindi, dan Bupati khalifah ditingkat kabupaten. Semuanya itu pemegang amanat baik buruknya akan dipertanggung jawabkan dihadapan Allah.

Rasyid Ridha juga mengedepankan pemerintahan dengan dipimpin oleh imam yang diangkat, hal ini ditujukan agar terhindar dari segala mudarat sehingga taat kepada Al-Qur'an dan Hadits nabi. Adapun pendapat Rasyid Ridha ini, mengadopsi ulamaulama zaman klasik dan dan pertengahan bukan kontemporer. Sementara itu, ia hidup dizaman modern yang mana sistem khilafah ingin dihapuskan. Dapat diambil garis besar bahwa keinginan Rasyid Ridha mempertahankan sistem pemerintahan yang khilafah mengikuti ulama terdahulu kurang efisien, sebab tantangan zaman sangatlah besar ditambah lagi dengan masuknya paham Barat yang kemudian diterapkan oleh Mustafa Kemal Attarturk. Paradigma pemisahan agama dengan politik dengan dalih mereka tidak menginginkan Islam menjadi sistem pemerintahan yang diterapkan dan menganggap memihak sebelah dan tidak seimbang, maka dalam hal ini bangsa Barat mulai menggaungkan istilah sekularisme agama ${ }^{37}$.

Sementara itu, sistem pemerintahan yang dibawa Rasyid Ridha bersifat absolut sehingga tidak memungkinkan orang lain mengemukakan pendapat. Baginya, pemerintahan yang syar'i ialah khilafah dan bukan berasal dari rakyat yang pemimpinnya dipilih melewati anggota alh al-halli wa al-a'qad atau yang disebut Rasyid Ridha dengan Ikhtiyar. Adapun sistem pemilihan dan pengunduran imam juga diatur lembaga tersebut. Dalam artikel lain menjelaskan untuk menentukan sebuah sistem pemerintahan yang bijak maka perlu adanya yaitu Syura38. Menurut bahasa syura berasal dari kata syawara yang merupakan Masdar dengan artinya yaitu musyawarah. Adapun pemilihan sistem ini Rasyid Ridha mengansumsi pada

${ }^{37}$ A. Jufri, "Konsepsi Politik Islam dan Realitas Relasi Islam dan Negara di Indonesia Pascareformasi", Farabi Jurnal Pemikiran Konstruktif Bidang Filsafat dan Dakwah, Vol. 18 No 2 Desember 2018, hlm. 48.

38 Ahmad Yamin, "Konsepsi Muhammad Rasyid Ridha Tentang Syura sebagai Azas Pemerintahan Islam", KONTEKSTUALITAS Jurnal Penelitian Sosial Keagamaan, hlm. 38 . 
hadist Nabi yaitu : "Dari Rafi” bin Khudaij

Rasulullah SAW bersabda : apa saja yang berkaitan dengan urusan agama (wahyu) kembalikan kepadaku, dan apa saja urusan yang berkaitan dengan dunia kalianlah yang lebih mengetahuinya". Pemilihan sistem musyawarah sebagai penentu aspek pemerintahan menurut Ridha memiliki beberapa keistimewaan yaitu ; melibatkan orang banyak, banyak masukkan ide yang variatif, dan relatif terjadinya kesalahan ${ }^{39}$.

Dalam membangun sebuah pemerintahan, Rasyid Ridha juga memakai konsep jihad yang mana hal tersebut dimaknai secara moderat ${ }^{40}$. Jihad dalam pemaknaan Ridha bukan hanya dalam hal peperangan akan tetapi sebuah upaya untuk mengentaskan masalah kenegaraan seperti kemiskinan, kebodohan, dan pembangunan bangsa. Sedangkan jihad yang dipakai ketika zaman Nabi Muhammad SAW yaitu mempertahankan diri (defensif) dari musuh yang akan menyerang. Maka dari itu, pendapat Ridha selaras dengan zamannya yaitu seperempat dari abad 20 ketika Mesir ingin merdeka dari penjajahan.

39 Ahmad Yamin, Konsepsi Muhammad Rasyid Ridha Tentang Syura sebagai Azas Pemerintahan Islam, p. 39

40 Isniyatul Khumayah (Mahasiswi Program Studi Ilmu Al-Qur'An dan Tafsir STAI Sunan Pandanaran), Konsep Jihad (Kompirasi Pemikiran Sayyid Qutb dengan Rasyid Ridha), p. 7
Ada beberapa bukti yang paling nyata dari Rasyid Ridha dalam dunia perpolitikan diantaranya $\left.{ }^{41} \quad ; \quad 1\right)$. ikut berperan aktif dalam perundingan dengan Inggris, 2).menjabat Presiden Kongres Syiria tahun 1920, 3).sebagai anggota delegasi Syiria-Palestina di Genewa tahun 1921，4).aktif dalam memperjuangkan kemerdekaan Syiria dari kekuasaan Turki Muda, 5).anggota Komite Politik di Kairo selama pemberontakan Syiria tahun 19251926.

\section{Kesimpulan}

Muhammad Rasyid Ridha dilahirkan di Qalamun, Kota Libanon pada tahun 1282H/1865M-1354 H/1935 H. Orang tua beliau yaitu al-Sayyid Ali Ridha yang merupakan seorang Sunni bermadzhab Syafi'i. Ketika Muhammad Rasyid Ridha kecil, ia menghabiskan waktunya dengan belajar dan membaca buku. Pendidikan Rasyid Ridha dimulai ketika ia memasuki sekolah bernama Madrasah al-Rasyidiyah, yaitu sekolah milik pemerintah di kota Tripoli.. Kemudian ia melanjutkan pendidikannya ke Madrasah al-Wathaniyah al-Islamiyyah yang didirikan oleh Syekh Husein al-Jisr ketika umur 18 tahun. Sayid Muhammad Rasyid Ridha

41 H.J. Suyuti Pulungan, MA.,(Guru Besar Fakultas Adab dan Humaniora dan Program Pacasarjana), Ide Jamaluddin al-Afghani, Muhammad Abduh dan Muhammad Rasyid Ridha tentang Negara dan Pemerintahan dalam Islam, IAIN Raden Fatah Palembang, p. 8 
meninggal pada Kamis, 23 Jumadil U'la $1354 \mathrm{H}$ atau bertepatan dengan 22

Agustus 1935.

Rasyid Ridha memaknai pembaharuan pemikiran Islam bahwa segala ilmu pengetahuan haruslah kembali kepada Al-Qur'an dan Sunnah, sebab dua sumber otentik inilah yang menyebabkan umat Islam dalam kejumudan serta ketertinggalan. Dalam bidang pendidikan beliau mempunya gagasan diantaranya dengan mendirikan sekolah bernama Madrasah al-Da'wah wa al-Irsyad pada tahun 1912 di Kairo. Muhammad Rasyid Ridha juga menekankan terhadap kurikulum Qur'ani sebab disamping kitab suci ia merupakan asas kemajuan peradaban. Dibidang politik, Rasyid Ridha menulis sebuah buku yang berjudul "Khilafah" menjelaskan bahwa untuk menegakkan urusan agama dan pemerintahan harus ada 3 unsur yaitu; khilafah, imamat dan imamat al-uzma, Sementara itu, dalam ijtihad beliau berpendapat bahwa banya ayat Al-Qur'an yang menjelaskan tentang hukum yaitu berjumlah 510, sedangkan hadits ahkam 500. Adapun pembagian ijtihad menurut beliau ada 2 yaitu ; pertama, ijtihad melalui ijma' yang dilakukan oleh mujtahid. Kedua, ijtihad yang dilakukan oleh penguasa dalam masalah pemerintahan, birokrasi, dan militer.

\section{Referensi}

1. Ahmad, Agus., Sejarah Pembaharuan Pemikiran dan Pembaharuan Rasyid Ridha.

2. Aklamsyah, Anas Amin, Pola Pemahaman Agama dan Pengembangan Kependidikan Kontribusi Rasyid Ridha, STIT Raden Wijaya, Journal Online of Education, Vol. 06 No. 02 November 2016.

3. Al-Qur'an al-Karim

4. Abd. Salam Arief, "Ijtihad dan Dinamika Hukum Islam", In Right Jurnal Agama dan Hak Azazi Manusia.

5. Baharun, H. Muhammad., Islam Idealitas Islam Realitas, (Jakarta ; Gema Insani, 2012).

6. Diana, Rasdah., Siswanto Masruri, Suwardono, "Etika Politik dalam Perspektif Islam", Jurnal TSAQAFAH Volume 14, No. 2 November 2018.

7. Fajri, Yasir,. Pemikiran Politik Islam Muhammad Rasyid Ridha.

8. Hadi, M. Khoirul, Pemikiran Politik Rasyid Ridha dalam Fiqh Munakahat, UIN Sunan Kalijaga.

9. H.J. Suyuti Pulungan, MA.,(Guru Besar Fakultas Adab dan Humaniora dan Program Pacasarjana), Ide Jamaluddin al-Afghani, Muhammad Abduh dan Muhammad Rasyid Ridha tentang Negara dan Pemerintahan dalam Islam, IAIN Raden Fatah Palembang.

10. Harahap, Sumber Mulia (Lecture of Syaria'h dan Law Science Faculty at IAIN Padangsidimpuan), Muhammad Rasyid Ridha Antara Modernisme dan Tradisionalisme,

11. Has, Abd Wafi, Ijtihad Sebagai Alat Pemecah Masalah Umat Islam, Sekolah Tinggi Keislaman Al-Hidayah (STIKA) Arjasa. 
12. Hilmi , Asep, "Pemikiran Modern Hukum Islam Rasyid Ridha", Staf Dinas Sosial Kabupaten Serang, TAZKIYA Jurnal Keislaman, Kemasyarakatan dan Kebudayaan.

13. Iman, H. Fauzul, "Muhammad Rasyid Ridha Sejarah dan Pemikirannya", Jurnal Al-Qalam, Vol. 19 No. 92, Januari-Maret 2002.

14. Irvansyah, Skripsi (Pemikiran Muhammad Rasyid Ridho tentang Pembaharuan Pendidikan Islam), Fakultas Tarbiyah dan Keguruan UIN Raden Intan Lampung, tahun 2018.

15. Jufri, A., "Konsepsi Politik Islam dan Realitas Relasi Islam dan Negara di Indonesia Pascareformasi", Farabi Jurnal Pemikiran Konstruktif Bidang Filsafat dan Dakwah, Vol. 18, No 2 Desember 2018.

16. Kalsum, Nyimas Umi,. Perkembangan Pemikiran dan Peradaban Islam pada Abad Modern, UIN Raden Patah.

17. Khumayah, Isniyatul (Mahasiswi Program Studi Ilmu Al-Qur'An dan Tafsir STAI Sunan Pandanaran), Konsep Jihad (Kompirasi Pemikiran Sayyid Qutb dengan Rasyid Ridha).

18. Lahmi, Ahmad,. "Sejarah Pendidikan Islam dari Masa ke Masa", Jurnal AKADEMIA.

19. Mappiaswan, Andi, (Skripsi Mahasiswa Sarjana Humaniora Jurusan Sejarah dan Kebudayaan Islam, Fakultas Adab dan Humaniora UIN Alauddin Makassar), Pemikiran Sayyid Muhammad Rasyid Ridha dalam Pengembangan Islam.

20. Masamah, Ulfa,. Mualimul Huda, "Pendidikan Islam, Pendidikan Politik, dan Dialog Antar Umat Beragama di Indonesia", Fikhrah; Jurnal Ilmu Aqidah dan Studi Keagamaan, STAIN Kudus, Desember: 2016.

21. Misno, "Redefinisi Ijtihad dan Taklid", Al-Mashalah Jurnal Hukum dan Pranata Sosial Islam.

22. Mugiono, "Perkembangan Pemikiran dan Peradaban Islam dalam Perspektif
Sejarah", Jurnal Ilmu Agama: Mengkaji Doktrin, Pemikiran, dan Fenomena Agama, Vol. 14 No 1 (2013).

23. Muhammad, Baharun, H., Islam Idealitas Islam Realitas, Gema Insani, (Jakarta ; 2012).

24. N. Arkiyah Artikel dengan Judul Tokoh Pembaharuan Muslim Arab Modern dan Kontribusinya terhadap Kepustakaan Islam (Muhammad Abduh dan Sayyid Muhammad Rasyid Ridha, Tahun 2017.

25. Nasruddin, Yusuf, "Perbandingan Pemikiran Muhammad Abduh dan Rasyid Ridha tentang Pendidikan", Jurnal Sosial Budaya, Vol. 8 No 01 Januari - Juni 2011.

26. Sanusi, Ahmad, (Mahasiswa Program Pascasarjana UIN SultanMaulana Hasanuddin Banten), Pemikiran Rasyid Ridha tentang Pembaharuan Islam.

27. Thalib, Moh. Amin Dahlan, Konsep Pendidikan Al-Qabisy dan M. Rasyid Ridha (Koedukasi dan Kurikulum).

28. Tiastuti, Kamilla Riska,. Makalah Pembaharuan Islam, https://www.academia.edu/42113023 /MAKALAH_PEMBAHARUAN ISLAM.

29. Wahid, Abd., (Dosen Jurusan Perbandingan Agama Fakultas Ushuluddin IAIN Antasari Banjarmasin), Pemikiran Politik dalam Islam, Ilmu Ushuludiin Januari, 2010 Vol. 9 No. 1.

30. Yamin, Ahmad., "Konsepsi Muhammad Rasyid Ridha Tentang Syura sebagai Azas Pemerintahan Islam", KONTEKSTUALITAS Jurnal Penelitian Sosial Keagamaan.

31. Yasin, Muhammad., Kegelisahan Muhammad Abduh dan Rasyid Ridha atas Keberagaman Umat Islam dan Pemikiran Tauhid Muhammad Abduh dan Rasyid Ridha.

32. Zainudin, "Pembaharuan Sistem Pendidikan Islam", Jurnal Risaalah, Vol. 1, No 1 Desember 2015. 